\title{
Seasonal variation in estuarine phytoplankton viability and its relationship with carbon dynamics in the Baltic Sea
}

\author{
Samu Elovaara $\mathbb{D}$ - Maria Degerlund • Daniel J. Franklin · Hermanni Kaartokallio • \\ Tobias Tamelander
}

Received: 26 August 2019/Revised: 8 April 2020/Accepted: 16 April 2020/Published online: 2 May 2020

(C) The Author(s) 2020

\begin{abstract}
Cell death drives the magnitude and community composition of phytoplankton and can result in the conversion of particulate organic carbon to dissolved organic carbon (DOC), thereby affecting carbon cycling in the aquatic food web. We used a membrane integrity probe (Sytox Green) to study the seasonal variation in the percentage of viable cells in the phytoplankton population in an estuary in the northern Baltic Sea for 21 months. The associated dissolved and particulate organic matter concentrations were also studied. The viable fraction of phytoplankton cells varied from $<20 \%$ to almost $100 \%$, with an average of $62 \%$. Viability was highest when a single phytoplankton group (diatoms or
\end{abstract}

Handling Editor: Emily M. Dangremond

S. Elovaara $(\varangle) \cdot$ M. Degerlund · T. Tamelander

Tvärminne Zoological Station, University of Helsinki,

J.A. Palménin tie 260, 10900 Hanko, Finland

e-mail: samu.elovaara@helsinki.fi

S. Elovaara · H. Kaartokallio

Finnish Environment Institute, Marine Research Center, Latokartanonkaari 11, 00790 Helsinki, Finland

D. J. Franklin

Bournemouth University, Christchurch House C208,

Talbot Campus, Fern Barrow, Poole BH12 5BB, UK

Present Address:

T. Tamelander

Novia University of Applied Sciences, Raseborgsvägen 9, 10600 Tammisaari, Finland dinoflagellates) dominated the community. Viability of sinking phytoplankton cells, including some motile species, was in general as high as in surface water. Changes in viability were not closely related to nutrient concentrations, virus-like particle abundance, seawater temperature or salinity. There was a weak but significant negative correlation between viability and DOC, although at this location, the DOC pool was mainly influenced by the inflow of riverine water. This study demonstrates that cell viability, and its relationship with carbon export, is highly variable in the complex microbial populations common within estuarine and coastal marine ecosystems.

Keywords Sytox Green $\cdot \mathrm{POC} \cdot \mathrm{DOC} \cdot$ Cell death $\cdot$ Organic matter sedimentation

\section{Introduction}

Studies in the past two decades have highlighted the prevalence of high proportions of damaged or dead cells within phytoplankton communities in different aquatic ecosystems (Veldhuis et al., 2001; Hayakawa et al., 2008; Rychtecký et al., 2014; Kozik et al., 2019; Vanharanta et al., 2020). Non-viable cells have been detected by membrane probes which identify cells with compromised membrane integrity, and which are therefore considered to be dead (Veldhuis et al., 2001; Agustí \& Sánchez, 2002; Kroemer et al., 2009) 
although defining the actual point of no-return for microbial death is difficult (Davey, 2011). Studies of cellular signaling, morphology and biochemistry have examined the possible causes of cell death pathways in phytoplankton, which in some cases, suggest the importance of programmed cell death as a loss process for some phytoplankton taxa (Bidle \& Falkowski, 2004; Franklin et al., 2006; Bidle, 2015). Programmed cell death can be initiated by diverse environmental stressors (Berges \& Falkowski, 1998; Berman-Frank et al., 2004; Lasternas et al., 2010; Ross et al., 2019), induced by viral activity (Brussaard et al., 2001; Laber et al., 2018), mediated by chemical communication among phytoplankton (Vardi et al., 2006; Poulin et al., 2018) and has been evolutionarily associated with community structuring and increased fitness among related phytoplankton (Durand et al., 2016).

The biogeochemical consequences of phytoplankton cell death can be diverse. Organic matter released from phytoplankton as dissolved organic matter (DOM; Thornton, 2014) is often highly bioavailable and is to a variable extent consumed and remineralized by pelagic heterotrophic bacteria (Jiao et al., 2010; Sarmento \& Gasol, 2012; Pedler et al., 2014). As dead phytoplankton cells lyse and part of their biomass is converted to DOM, cell death can be expected to contribute more to the pelagic DOM pool and channel more carbon through the microbial loop (Orellana et al., 2013), and less to particulate organic matter sinking and the biological pump (Kwon et al., 2009). There is even evidence that polyunsaturated aldehydes released by some phytoplankton, especially upon cell death, may stimulate the remineralization of particulate organic matter, which would further benefit pelagic carbon cycle at the cost of organic matter sedimentation (Edwards et al., 2015). However, the effect of cell death on carbon cycling is not always as simple since synchronized PCD-induced cell death may initiate the collapse of a phytoplankton bloom and therefore contribute to sinking of $\mathrm{C}$, as shown for Trichodesmium by Bar-Zeev et al. (2013). Some phytoplankton undergoing cell death produce transparent exopolymer particles (Berman-Frank et al., 2007; Kahl et al., 2008; Thornton \& Chen, 2017). These compounds can on the one hand produce sustenance for pelagic heterotrophic bacteria (Carrias et al., 2002), but on the other hand they may promote particle aggregation and increase carbon export (Turner, 2015).
The biogeochemical effects of phytoplankton mortality have mainly been studied in oligotrophic marine environments where DOM release from phytoplankton correlates with bacterial production (Brussaard et al., 1995; Agustí \& Duarte, 2013; Lasternas et al., 2013). However, there have been fewer in situ investigations of phytoplankton mortality in highly productive coastal seas such as the Baltic Sea. Estimates of the effect of phytoplankton mortality on carbon cycling in the coastal regions are important since they have been estimated to be responsible for $\sim 12 \%$ of the marine primary production and $\sim 85 \%$ of the total carbon burial in the ocean (Dunne et al., 2007). The Baltic Sea suffers from eutrophication due to its history of high-nutrient inputs (Fleming-Lehtinen et al., 2008). Terrestrial DOM contributes to the DOM pool especially in coastal zones (Hoikkala et al., 2015) which might reduce the importance of DOM released from dying phytoplankton, a process expected to be less significant in the open Baltic Sea. The shallow depth of the Baltic Sea means that the sedimentation times are short, which may favor sinking over disintegration in the water column as a loss process for phytoplankton. Also, the relative importance of sinking versus lysis is likely to be influenced by the phytoplankton community composition. Fast sinking phytoplankton, such as large diatoms, contribute effectively to the biological pump (Agusti et al., 2015), whereas slow sinking buoyant or motile phytoplankton, such as dinoflagellates, are expected to be mainly consumed in the mixed layer, contributing to the pelagic particulate and dissolved organic carbon (POC and DOC, respectively) pools (Tamelander \& Heiskanen, 2004). The spring bloom in the Baltic Sea has traditionally been dominated by diatoms, but there is evidence of an increase in dinoflagellate-dominated spring blooms in recent years (Klais et al., 2011), which may affect the cycling of carbon and nutrients (Spilling et al., 2018).

The extent of seasonal variation in phytoplankton mortality in the Baltic Sea is not known and is poorly known elsewhere. It is also not known how phytoplankton mortality differs under variable trophic conditions and which endo- or exogenous factors drive the changes in mortality. In this study, we investigated the seasonal variation in the proportion of dead cells within the phytoplankton community and the possible environmental drivers for phytoplankton cell death in an estuary in the northern Baltic Sea. 
Especially nutrient depletion was focused on, because phytoplankton growth around the study area is often limited by nitrogen (Tamminen \& Andersen, 2007). We also studied the possible implications of phytoplankton cell death for POC and DOC partitioning.

We used a membrane integrity probe (Sytox Green nucleic acid stain) to detect cells with compromised membranes (Veldhuis et al., 2001; Peperzak \& Brussaard, 2011). Membrane permeability was chosen as an indicator because it detects a crucial aspect of cell death related to organic matter cycling, namely the compromised membrane integrity allowing for the release of cellular contents. We refer to the proportion of phytoplankton with intact membranes to total phytoplankton abundance as viability of the phytoplankton community. This terminology has been widely used in similar sense in literature dealing with phytoplankton cell death and lysis (Brussaard et al., 2001; Agustí \& Sánchez, 2002) and should not be directly interpreted according to the definition in classical microbiology where viability refers to the ability to divide. Heterotrophic bacteria were enumerated and divided into high and low nucleic acid (HNA and LNA, respectively) fractions to assess if release of DOM from dying cells could be seen as direct incorporation into bacterial biomass or shifts in HNA or LNA populations due to changes in productivity or community composition (Bouvier et al., 2007). Virus-like particle (VLP) abundance was measured to observe occurrence of co-variation between VLP abundance and phytoplankton viability, a possible indication of viral lysis as a cause for phytoplankton cell death. We hypothesized that an increased proportion of dead cells would be associated with an increase in DOM production as indicated by (1) increased DOM concentration, (2) increased bacterial abundance and/or (3) an increased sinking of aggregated organic matter.

We also considered the viability of sinking phytoplankton cells. It is well documented that dead or senescent cells of non-motile species sink faster than their living counterparts even if there are no visible differences in the cells (Smayda \& Boleyn, 1965; Eppley et al., 1967; Titman \& Kilham, 1976). Padisák et al. (2003) have discussed that this 'vital factor' may be due to loss of certain flotation aids, such as motility and mucilaginous protuberances in the dying cells. Also, metabolically controlled sinking regulation mechanisms in diatoms (Gemmell et al., 2016) could be assumed to be compromised by damaged membranes. Accelerated sinking of dying cells may also be caused by TEP release from damaged cells and the subsequent aggregation (Kahl et al., 2008). In motile species, dying would increase sinking rate assuming that cessation of flagella motion comes before membrane permeabilization in the cell death pathway. We therefore investigated the effect of viability on sinking by comparing the proportion of membrane permeable cells in the sediment trap to that in the surface water. A significantly higher proportion of dying cells in the sediment traps than in surface water would indicate that cell death increases the sinking of phytoplankton. A significantly lower proportion would instead indicate that cell death and subsequent lysis contribute to keeping phytoplankton-derived carbon in the pelagic system. We hypothesized that especially during blooms consisting of phytoplankton species known for low sinking rates that viability of cells in the sinking fraction would be lower than in the surface water suspended fraction.

\section{Materials and methods}

\section{Sampling and sampling site}

Sampling was carried out in an estuarine archipelago in southern coast of Finland in 2015 and 2016. The sampling site, Storfjärden $\left(59^{\circ} 86^{\prime} \mathrm{N}, 23^{\circ} 26^{\prime} \mathrm{W}\right)$, is an intensely studied site at the outskirts of Karjaanjoki Estuary close to University of Helsinki Tvärminne Zoological Station (TZS). Sampling started in March 2015 at the beginning of the spring bloom and continued until the December 2016 (21 months). Sampling was conducted monthly in late autumn and winter, and every 1 or 2 weeks during the highly productive periods.

Surface water $(0.5-1 \mathrm{~m})$ samples were collected in the morning using a Limnos water sampler (Limnos OY, Turku). Temperature and salinity were measured with a CTD for the total water depth $(\sim 30 \mathrm{~m})$ at the sampling site. Simultaneously two 1.81 sediment traps were deployed below the euphotic zone at $20 \mathrm{~m}$ depth close to the sampling site (within $100 \mathrm{~m}$ ). The sediment traps were acrylic cylinders with inner diameter of $7.2 \mathrm{~cm}$ and height-diameter ratio of $6: 1$, filled with filtered seawater with salinity adjusted to 10 PSU. No preservatives were added to the traps. The 
duration of the deployments was 24 h. In 2015 only, a water sample was collected also from $20 \mathrm{~m}$. Water column samples and sediment trap samples were processed immediately after collection at the TZS.

\section{Laboratory analyses}

From each surface sample the following variables were measured in triplicates (in 2015 only technical triplicates from a single water sample, in 2016 three water samples per sampling): chlorophyll $a(\mathrm{Chl} a)$, particulate organic carbon and nitrogen $(\mathrm{POC} / \mathrm{N})$, dissolved organic carbon and nitrogen $(\mathrm{DOC} / \mathrm{N})$ and bacterial abundance. These same variables were measured in $20 \mathrm{~m}$ and the sediment trap samples, except for DOC/N which was not measured in the trap. Phytoplankton community composition and viability, and inorganic nutrients $\left[\mathrm{NH}_{4}{ }^{+}, \mathrm{NO}_{3}{ }^{-}\right.$(including $\mathrm{NO}_{2}{ }^{-}$), $\left.\mathrm{PO}_{4}{ }^{3-}, \mathrm{Si}\right]$ were determined in single surface samples. In 2015, viability was also measured in $20 \mathrm{~m}$ and the sediment trap.

\section{Phytoplankton community composition} and viability

Phytoplankton community composition was examined in Lugol-fixed surface samples from the start of the sampling period until June 2016. Using an inverted Leica DMIL microscope with phase contrast optics, phytoplankton species abundance and biomass were determined according to the Utermöhl technique recommended in the HELCOM monitoring manual (2015). Phytoplankton carbon content was estimated according to Menden-Deuer \& Lessard (2000), as described in HELCOM (2015). All encountered phytoplankton were identified to species, genus, or higher taxonomic level. For further analyses, the phytoplankton community was simplified into the following broad taxonomic groups: diatoms, dinoflagellates, other flagellates, cyanobacteria, and other phytoplankton. Abundance of the diatom Skeletonema marinoi Sarno \& Zingone, 2005 was examined throughout the sampling period on species level as it was the dominant species through the 2015 spring bloom. Shannon index was calculated for each sampling according to
$H=\sum_{i=1}^{R} p_{i} \ln p_{i}$,

where $p$ is the proportion of biomass of $i$ th of the five previously mentioned broad groups (excluding $S$. marinoi) to total phytoplankton biomass, and $R$ is the total number of groups (5).

The ratio of living to dead cells in the phytoplankton community was determined by epifluorescence microscopy counting of membrane permeable cells. $3 \mathrm{ml}$ of untreated surface sample was mixed with Sytox Green nucleic acid stain to final concentration of $0.5 \mu \mathrm{M}$ and incubated for $10 \mathrm{~min}$. Samples were counted with an inverted epifluorescence microscope (Leitz Dialux 20) under blue (450-490 nm) excitation using Utermöhl cuvettes. Green fluorescent (membrane permeable) and red fluorescent (membrane impermeable) phytoplankton cells were counted (Fig. 1). At least 200 cells were counted from each sample and this was used to calculate viability for the whole community. If cell density was $<200$ cells in the cuvette, some of the sample water was concentrated by sieving through a $10-\mu \mathrm{m}$ plankton net and thereby reflecting viability of phytoplankton cells larger than $10 \mu \mathrm{m}$ only. When cell density was extremely low, 200 cells per cuvette was not always achieved.

To optimize the balance between sample coverage and information per sample we chose to determine viability for a fixed quantity subset of the total community (i.e., viability was not determined separately for individual taxa). When comparing bulk viability to environmental variables with units of mass (e.g., nutrient and organic matter concentrations) it was unavoidably assumed that the percentage of living cells corresponds to an equal proportion of phytoplankton biomass. This is however not always the case, since occasionally a small phytoplankton species might numerically dominate the pool of dying cells leading to exaggerated estimate of the biomass of the dead cells. We also had to accept the presumption that all taxa stain equally with Sytox Green which is not always the case (Peperzak \& Brussaard, 2011). Also, different life cycle morphologies might show different staining patterns, but at least dinoflagellate cysts seem to react to Sytox Green staining as the vegetative cells do (Gregg \& Hallegraeff, 2007). 

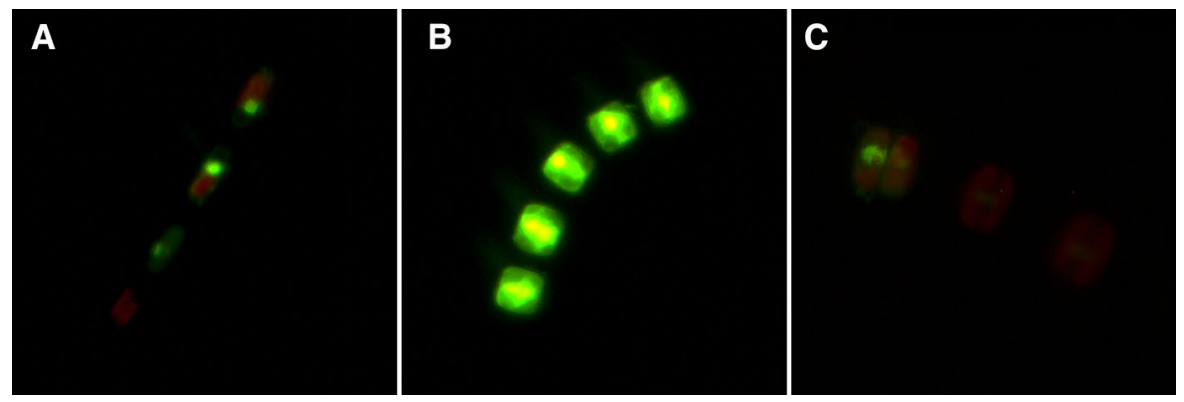

Fig. 1 A Microscopic images (not to scale) of Sytox Green stained phytoplankton cells demonstrating Chl $a$ autofluorescence (red) and Sytox Green fluorescence (green). A partially

\section{Chemical measurements}

For Chl $a$ analyses $100 \mathrm{ml}$ of sample water was vacuum filtered on GF/F glass fiber filters (Whatman). Chl $a$ was extracted in $10 \mathrm{ml}$ of ethanol overnight in dark in glass scintillation vials. Samples were analyzed the following day or stored at $-20^{\circ} \mathrm{C}$ until analysis within the same week. Chl $a$ was measured fluorometrically with a Varian Cary Eclipse spectrofluorometer. $300 \mu \mathrm{l}$ of sample was added into a well plate and the fluorescence was measured (excitation/ emission: 430/670 nm). Fluorescence intensity was converted to $\mathrm{Chl} a$ concentration using $\mathrm{Chl} a$ standards (Sigma).

For $\mathrm{POC} / \mathrm{N} 100 \mathrm{ml}$ of sample water was vacuum filtered through pre-combusted $\left(450^{\circ} \mathrm{C}, 4 \mathrm{~h}\right) \mathrm{GF} / \mathrm{F}$ filters. Filters were individually wrapped in aluminum foil and stored at $-20^{\circ} \mathrm{C}$ until analysis. Analysis was performed using Europa Scientific ANCA-MS 20-20 $15 \mathrm{~N} / 13 \mathrm{C}$ mass spectrometer. For DOC/N measurements, $20 \mathrm{ml}$ of water was syringe filtered through acid washed and pre-combusted $\mathrm{GF} / \mathrm{F}$ filters $\left(450^{\circ} \mathrm{C}\right.$, $4 \mathrm{~h}$ ) into acid-washed and pre-combusted glass vials. The filtered sample was acidified with $80 \mu \mathrm{l}$ of $2 \mathrm{M}$ $\mathrm{HCl}$ and stored in dark in room temperature until analysis with Shimadzu TOC-V CPH total organic carbon analyzer. Nutrients were measured according to Grasshoff et al. (1983) immediately after sampling.

Sedimentation rates of POC, PON and Chl $a$ were calculated based on the concentration of the substance in the trap sample, the total volume of the trap sample, opening area of the trap, and collection time, thus providing sedimentation rates in units of mass per square meter and day. stained Skeletonema marinoi, B fully stained Thalassiosira sp. C partially stained and unstained Thalassiosira $\mathrm{sp.}$

\section{Bacteria and virus-like particles}

For counting of bacterial and VLP abundance $1.8 \mathrm{ml}$ of sample water was stored in 2.0-ml cryovials, fixed with $300 \mu \mathrm{l}$ of $10 \%$ paraformaldehyde with $0.5 \%$ glutaraldehyde solution, incubated in room temperature for $10-30 \mathrm{~min}$ and stored in $-80^{\circ} \mathrm{C}$. Samples were counted with flow cytometry [2015 samples: CyFlow Cube8 flow cytometer (Partek $\mathrm{GmbH}$, Münster, Germany), 2016 samples: Accuri C6 Plus (BD)] mainly as in Gasol et al. (1999). $120 \mu \mathrm{l}$ of sample was diluted in $1080 \mu \mathrm{l}$ of $1 \times$ TE-buffer, and 0.5 - $\mu \mathrm{m}$ beads (Polysciences Fluoresbrite Calibration Grade 0.5 Micron YG Microspheres) and SYBR Green I nucleic acid stain (final concentration 1:10,000 vol:vol) were added to each sample. Samples where then incubated in room temperature for $\sim 10$ min before flow cytometric analysis. Cytometer data were analyzed with FCS Express 5 software (De Novo software). The bacterial fraction was divided into HNA and LNA populations, and the VLP population was also quantified, based on side scatter and green fluorescence (nucleic acid-bound SYBR Green I) intensity biplots. Location and properties of the VLP population were verified against bacteriophage control samples purified according to Luhtanen et al. (2014).

Pooling the data according to seasons

Temperature, Chl $a$ and inorganic $\mathrm{N}$ concentrations (due to $\mathrm{N}$ being the main limiting nutrient in the past and according to our data) were used to divide the two study years into four biologically relevant seasons (winter, spring bloom, summer and fall, Fig. 2). Winter was defined as the season when inorganic 

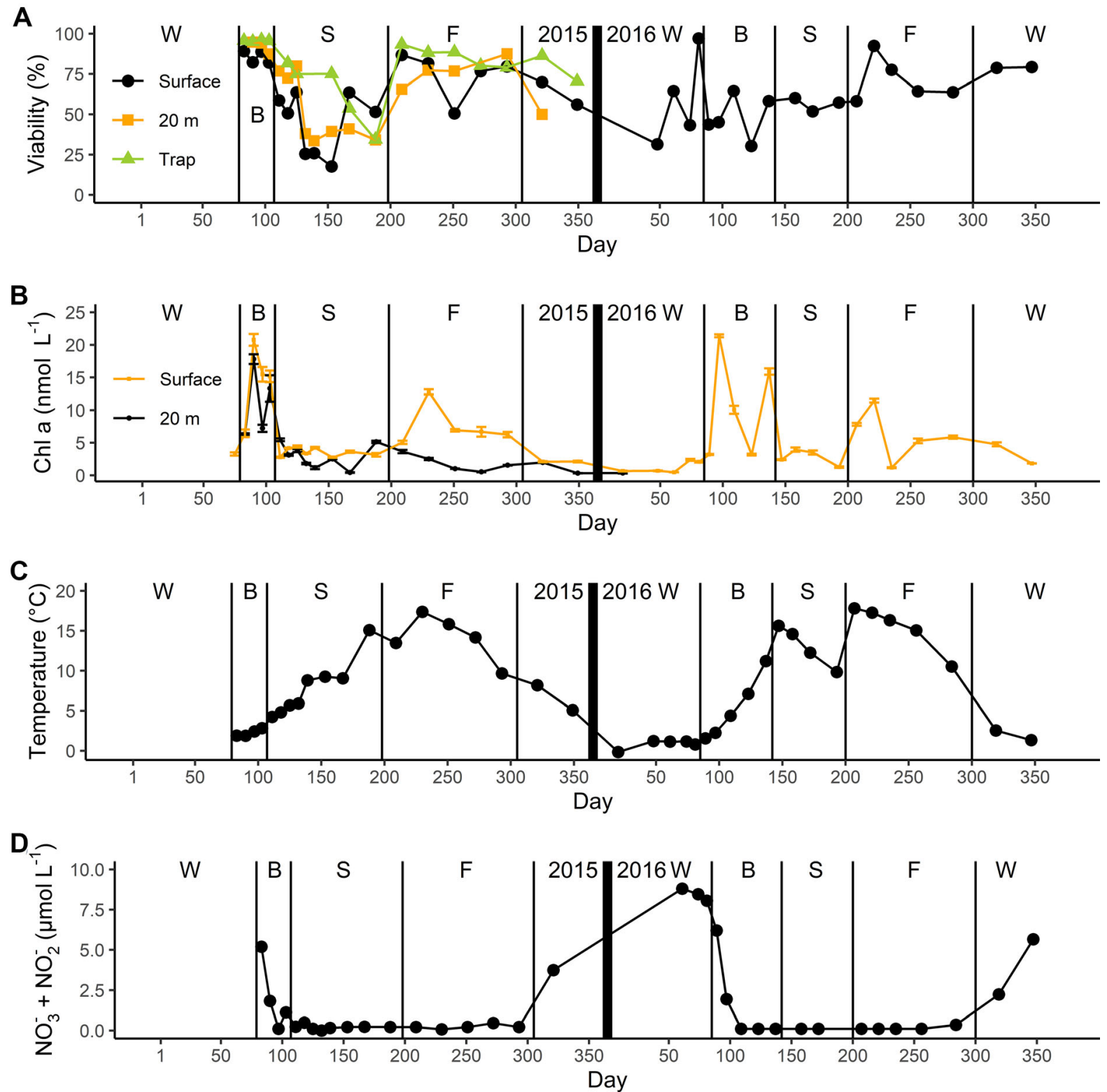

Fig. 2 A Percentage of viable cells, B Chl $a$ concentration (error bars indicate one standard deviation), $\mathbf{C}$ temperature and D $\mathrm{NO}_{3}{ }^{-}$(including $\mathrm{NO}_{2}{ }^{-}$) concentration through the total sampling period in surface water (circles) in $20 \mathrm{~m}$ water column

nitrate concentration is high and temperature and $\mathrm{Chl}$ $a$ concentration are low. Spring bloom was set to start at the steep increase in Chl $a$ concentration and the decline in inorganic nitrate concentration, and to end at the collapse of the Chl $a$ concentration. Summer was defined as the period with low Chl $a$ and increasing temperature, although during the summer of 2016 there was a long upwelling event and the temperature (squares) and in $20 \mathrm{~m}$ sediment trap (triangles) Seasons are divided by vertical lines. W, B, S and F stand for winter, spring bloom, summer and fall, respectively

actually decreased during the summer. Fall was set to start at the onset of late summer bloom as indicated by the increasing Chl $a$ values and onset of temperature decline, and to end when the inorganic nitrate concentration started to rise. These definitions of seasons follow the annual abiotic and biotic dynamics in the Baltic Sea and provide a regional context to our findings. Sampling events from both years were 
Table 1 Variables (means and standard deviations) divided into seasons

\begin{tabular}{|c|c|c|c|c|c|}
\hline Variable & All samplings & Winter & Spring bloom & Summer & Fall \\
\hline Viability (\%) & $62.2(20.1)$ & $65.1(21.1)$ & $64.9(21.9)$ & $47.9(16.7)$ & $73.2(13.3)$ \\
\hline Chl $a\left(\right.$ nmol 1 $\left.^{-1}\right)$ & $5.9(5.4)$ & $2.0(1.3)$ & $12.4(6.9)$ & $3.4(0.9)$ & $6.9(3.2)$ \\
\hline POC $\left(\mu \mathrm{mol} 1^{-1}\right)$ & $49.2(24.0)$ & $30.4(5.0)$ & $68.9(35.0)$ & $45.2(11.6)$ & $53.3(15.6)$ \\
\hline $\mathrm{PON}\left(\mu \mathrm{mol} \mathrm{1^{-1 } )}\right.$ & $5.0(3.2)$ & $2.2(0.9)$ & $7.7(4.2)$ & $4.0(1.4)$ & $6.1(2.1)$ \\
\hline $\mathrm{DOC}\left(\mu \mathrm{mol} 1^{-1}\right)$ & $417.0(30.6)$ & $414.2(23.1)$ & $416.9(41.2)$ & $422.1(32.9)$ & $415.4(28.1)$ \\
\hline$\left(\mu \mathrm{mol} 1^{-1}\right)$ & $18.0(2.5)$ & $16.4(1.4)$ & $17.0(2.9)$ & $18.7(2.7)$ & $19.5(1.9)$ \\
\hline Salinity (psu) & $5.5(0.4)$ & $5.6(0.6)$ & $5.5(0.5)$ & $5.5(0.4)$ & $5.7(0.3)$ \\
\hline Temperature, $\mathrm{C}$ & $8.0(5.8)$ & $2.4(2.6)$ & $4.0(3.2)$ & $9.6(4.0)$ & $14.7(2.8)$ \\
\hline $\mathrm{NO}_{3}^{-}+\mathrm{NO}_{2}^{-}\left(\mu \mathrm{mol} 1^{-1}\right)$ & $1.6(2.7)$ & $6.2(2.7)$ & $1.9(2.3)$ & $0.2(0.1)$ & $0.2(0.1)$ \\
\hline $\mathrm{NH}_{4}^{+}\left(\mu \mathrm{mol} 1^{-1}\right)$ & $0.1(0.1)$ & $0.3(0.3)$ & $0.1(0.1)$ & $0.1(0.0)$ & $0.1(0.1)$ \\
\hline $\mathrm{PO}_{4}{ }^{3-}\left(\mu \mathrm{mol} \mathrm{l} 1^{-1}\right)$ & $0.3(0.3)$ & $0.7(0.2)$ & $0.2(0.3)$ & $0.1(0.1)$ & $0.2(0.1)$ \\
\hline $\mathrm{Si}\left(\mu \mathrm{mol} 1^{-1}\right)$ & $12.7(5.1)$ & $20.0(3.3)$ & $13.0(5.7)$ & $8.5(1.5)$ & $12.2(2.2)$ \\
\hline Heterotrophic bacteria $\left(\mathrm{ml}^{-1}\right)$ & $\begin{array}{l}3.1 \mathrm{E}+06 \\
\quad(1.6 \mathrm{E}+06)\end{array}$ & $\begin{array}{l}1.5 \mathrm{E}+06 \\
(8.0 \mathrm{E}+05)\end{array}$ & $\begin{array}{l}2.0 \mathrm{E}+06 \\
(4.0 \mathrm{E}+05)\end{array}$ & $\begin{array}{l}3.7 \mathrm{E}+06 \\
(1.4 \mathrm{E}+06)\end{array}$ & $\begin{array}{l}4.7 \mathrm{E}+06 \\
\quad(1.2 \mathrm{E}+06)\end{array}$ \\
\hline HNA bacteria $\left(\mathrm{ml}^{-1}\right)$ & $\begin{array}{l}1.0 \mathrm{E}+06 \\
(5.0 \mathrm{E}+05)\end{array}$ & $\begin{array}{l}5.0 \mathrm{E}+05 \\
\quad(2.0 \mathrm{E}+05)\end{array}$ & $\begin{array}{l}9.0 \mathrm{E}+05 \\
\quad(2.0 \mathrm{E}+05)\end{array}$ & $\begin{array}{l}1.4 \mathrm{E}+06 \\
\quad(6.0 \mathrm{E}+05)\end{array}$ & $\begin{array}{l}1.3 \mathrm{E}+06 \\
\quad(3.0 \mathrm{E}+05)\end{array}$ \\
\hline LNA bacteria $\left(\mathrm{ml}^{-1}\right)$ & $\begin{array}{l}2.0 \mathrm{E}+06 \\
\quad(1.2 \mathrm{E}+06)\end{array}$ & $\begin{array}{l}1.0 \mathrm{E}+06 \\
(6.0 \mathrm{E}+05)\end{array}$ & $\begin{array}{l}1.1 \mathrm{E}+06 \\
\quad(3.0 \mathrm{E}+05)\end{array}$ & $\begin{array}{l}2.3 \mathrm{E}+06 \\
(8.0 \mathrm{E}+05)\end{array}$ & $\begin{array}{l}3.4 \mathrm{E}+06 \\
\quad(9.0 \mathrm{E}+05)\end{array}$ \\
\hline $\mathrm{VLP}, \mathrm{ml}^{-1}$ & $\begin{array}{l}7.8 \mathrm{E}+06 \\
(4.8 \mathrm{E}+06)\end{array}$ & $\begin{array}{l}7.7 \mathrm{E}+06 \\
(4.7 \mathrm{E}+06)\end{array}$ & $\begin{array}{l}6.0 \mathrm{E}+06 \\
\quad(4.6 \mathrm{E}+06)\end{array}$ & $\begin{array}{l}6.2 \mathrm{E}+06 \\
(4.3 \mathrm{E}+06)\end{array}$ & $\begin{array}{l}1.1 \mathrm{E}+07 \\
\quad(4.1 \mathrm{E}+06)\end{array}$ \\
\hline $\begin{array}{l}\text { POC sedimentation }\left(\mu \mathrm{mol} \mathrm{m} \mathrm{m}^{-2}\right. \\
\left.\text { day }^{-1}\right)\end{array}$ & $40.4(29.3)$ & $18.9(7.4)$ & $33.8(12.4)$ & $48.9(14.5)$ & $53.2(46.0)$ \\
\hline $\begin{array}{l}\text { PON sedimentation, }\left(\mu \mathrm{mol} \mathrm{m}{ }^{-2}\right. \\
\text { day }^{-1} \text { ) }\end{array}$ & $4.3(2.9)$ & $1.7(1.0)$ & $3.4(1.1)$ & $5.4(2.0)$ & $5.9(4.1)$ \\
\hline $\begin{array}{l}\text { Chl } a \text { sedimentation }\left(\mathrm{nmol} \mathrm{m}^{-2}\right. \\
\text { day }^{-1} \text { ) }\end{array}$ & $3.1(2.4)$ & $0.7(0.4)$ & $5.6(2.4)$ & $3.0(1.3)$ & $2.6(1.3)$ \\
\hline
\end{tabular}

All other variables except sedimentation rate are measured in surface water. Measurements for each season from total sampling period have been pooled. Samplings were divided into seasons based on changes in temperature, Chl $a$ concentration and inorganic $\mathrm{N}$ (Fig. 2B-D)

pooled into these seasons, and any reference to individual season will therefore concern samplings from both years, unless specified otherwise.

\section{Statistical analyses}

Differences among seasons or between sampling depths were analyzed using one-way ANOVA when assumptions were met, or with Welch-ANOVA when heteroscedasticity prevented the reliable use of regular one-way ANOVA. Games-Howell post-hoc test was applied on the significant Welch-ANOVA results. Differences in ANOVA analyses were considered significant at a $P$ value $<0.001$. Dependence between continuous environmental variables was analyzed with linear regression. The effect of environmental variables on viability was tested using a generalized linear model (GLM) with beta distribution. The effect of other variables on phytoplankton or bacterial abundance was tested using GLM with negative binomial distribution. Regression analyses were performed on the whole sampling period and separately for each season. Model selection for GLM was based on Akaike information criterion. Data exploration was performed following the procedure described in Zuur et al. (2010) as closely as possible.

\section{Results}

Variation in phytoplankton viability

Phytoplankton viability varied from 18 to $97 \%$ during the monitoring period (Fig. 2A). On average, viability 


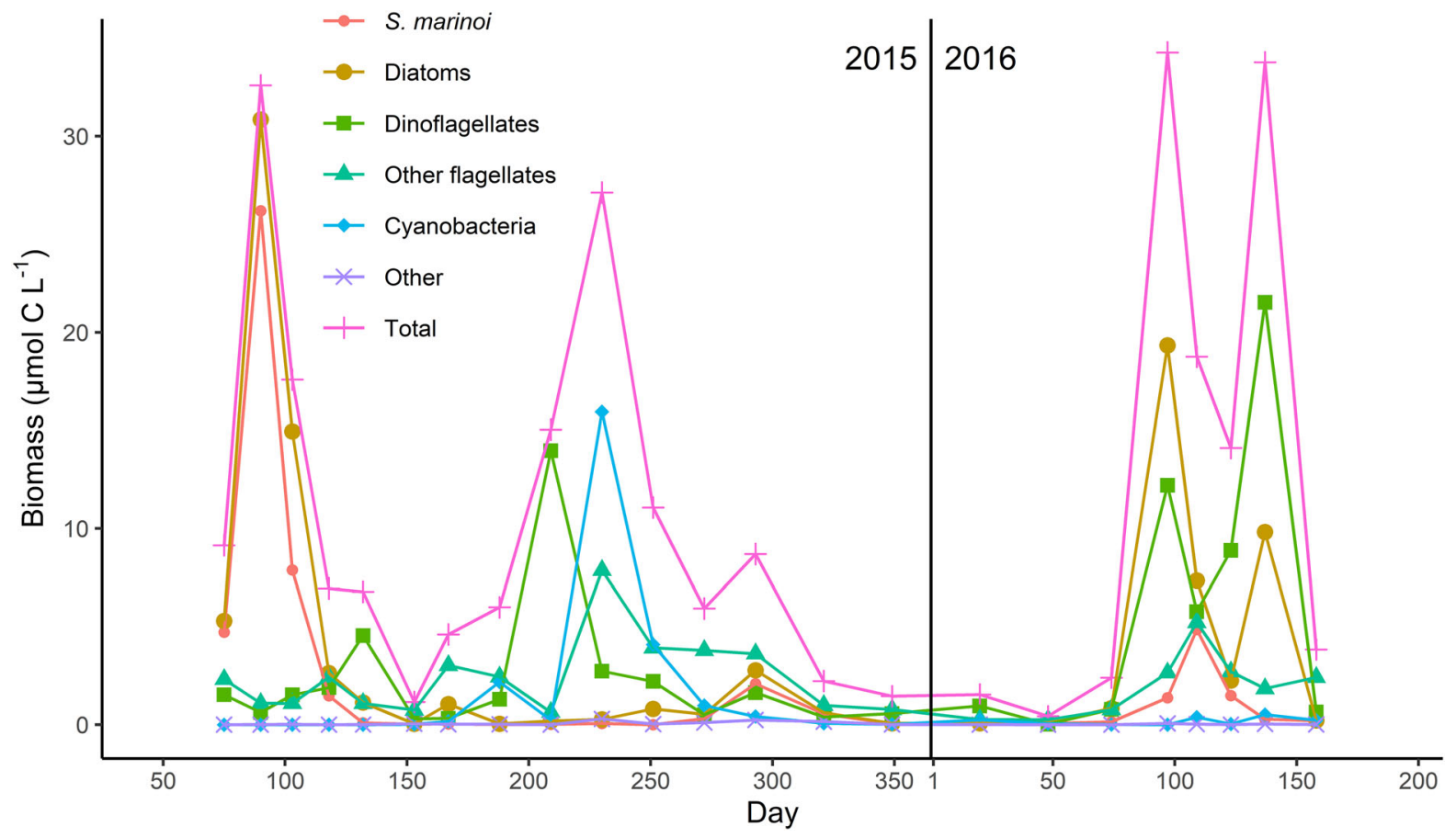

Fig. 3 Biomass of main groups within the phytoplankton community through the total sampling period

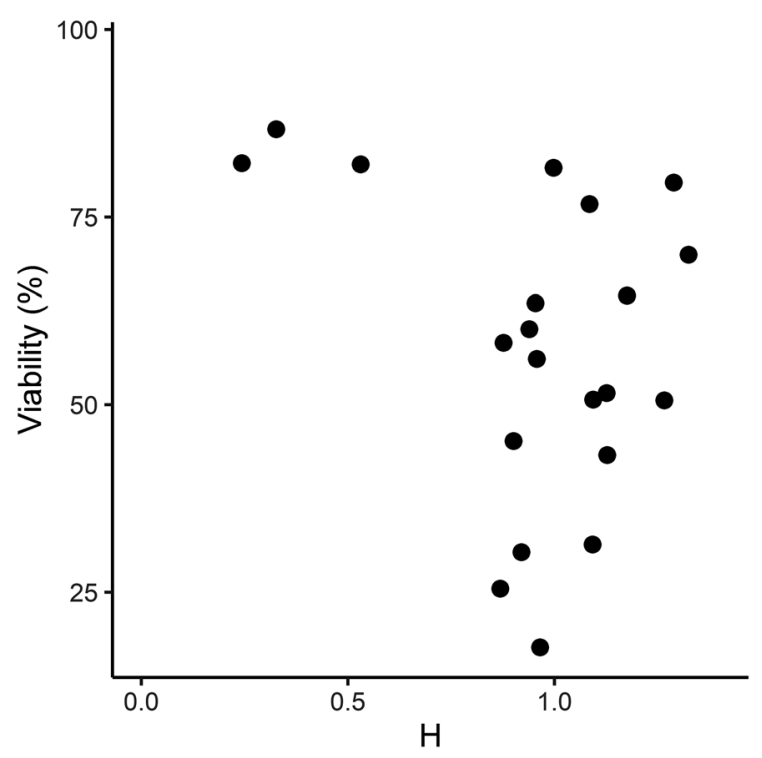

Fig. 4 Shannon index $(H)$ calculated based on the phytoplankton groups used in Fig. 3 presented against phytoplankton community viability

was lowest in summer (Table 1). This was especially pronounced during the summer of 2015, when the viability in surface water was $\sim 25 \%$ or less for three consecutive measurements, covering a period of
21 days. Highest viabilities were recorded during spring blooms and fall when the phytoplankton density was also higher. In general, viability was high when total phytoplankton abundance was high, but abundance explained only a small part of the variation in viability (beta regression, pseudo $R^{2}=0.22$, $P=0.0189$ ). When seasons were analyzed individually this relationship was only significant during winter (beta regression, pseudo $R^{2}=0.88$, $P<0.001)$ and near significant during spring bloom (beta regression, pseudo $R^{2}=0.57, P=0.0757$ ). In summer there was no relationship between phytoplankton abundance and viability, and in fall the relationship was negative (beta regression, pseudo $R^{2}=0.59, P=0.0119$ ).

Immediately following the 2015 spring bloom, when most of the nutrients had been consumed, phytoplankton viability dropped quickly to its minimum value. Later in the summer phytoplankton biomass again rose to high densities and viability increased again despite nutrients being in low concentrations. $\mathrm{NO}_{3}{ }^{-}$concentration was low (often below the accurate determination limit of $0.25 \mu \mathrm{mol} 1^{-1}$ ) during the productive season for both years. $\mathrm{PO}_{4}{ }^{3-}$ not only was occasionally depleted during the productive 

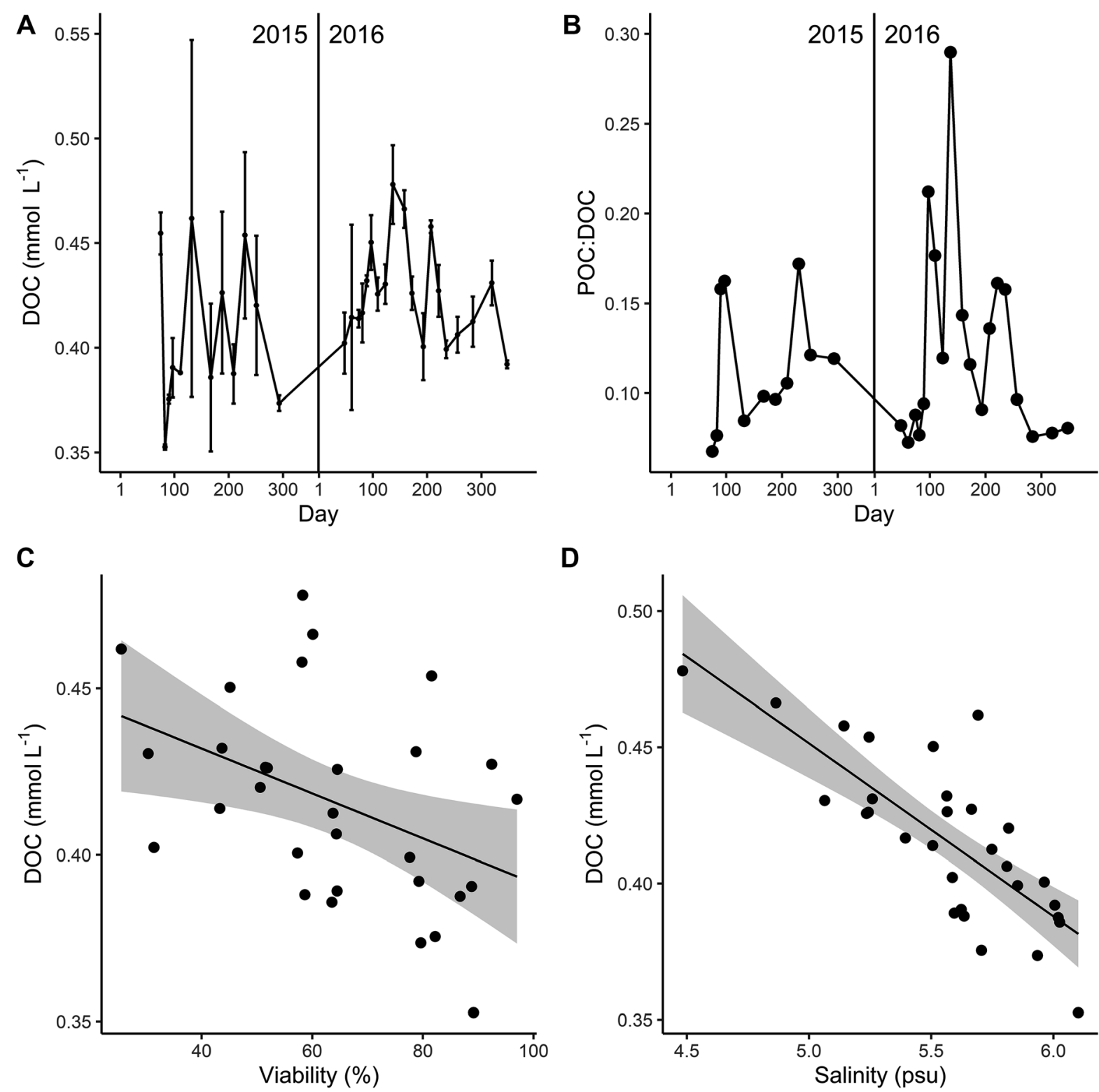

D

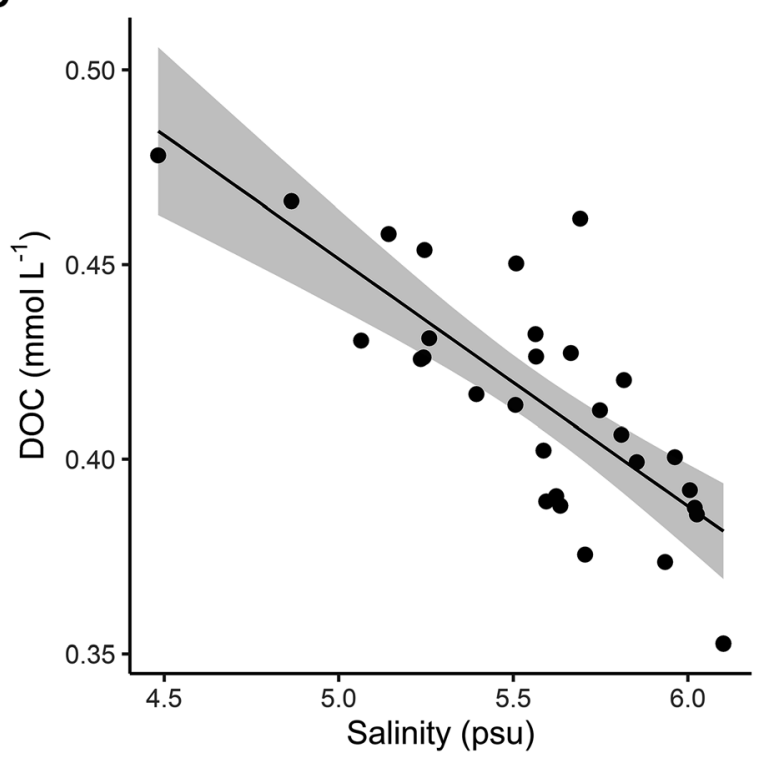

Fig. 5 DOC concentration (error bars indicate one standard deviation) (A) and POC:DOC ratio (B) through the total sampling period. C Relationship between DOC concentration

season but also showed some higher values. No relationship between viability and abundance of viruslike particles was detected.

The phytoplankton communities during the spring blooms of 2015 and 2016 differed in species composition (Fig. 3). In 2015 the spring bloom phytoplankton community consisted mainly of diatoms and it was dominated by a single diatom species $S$. marinoi. The duration of the 2015 spring bloom was also about

and phytoplankton viability (linear regression slope and 95\% confidence intervals). D Relationship between DOC and salinity (linear regression slope and $95 \%$ confidence intervals)

20 days shorter than in 2016. In 2016 the spring bloom community was mixed; the initial diatom dominance shifted to dinoflagellate dominance toward the end of the bloom, but both groups were present during the whole bloom. The dominant species of 2015 spring bloom, $S$. marinoi, was only present in low abundance in 2016 with a small abundance peak during the lower biomass transition period from diatom to dinoflagellate dominance. The bloom period in the fall of 2015 
was mixed with a succession from dinoflagellates to cyanobacteria. Periods of dominance by a single phytoplankton group, as identified by low group level (taxa presented in Fig. 3) Shannon index values, always co-occurred with high viability (Fig. 4).

The viability in the sediment traps was in general slightly higher than in surface water or $20 \mathrm{~m}$ (Fig. 2A) but the average viability among the different depths did not differ significantly. During 2015 spring bloom viability of sinking phytoplankton, which consisted mainly of $S$. marinoi, was $\sim 95 \%$. High viability of sinking cells was not restricted to diatoms only, since the same phenomenon was observed during the autumn bloom when dinoflagellate and cyanobacteria dominated. In general, all kinds of phytoplankton cells, even motile dinoflagellates, were found in the sediment traps.

Phytoplankton viability and pelagic organic matter

DOC correlated negatively with phytoplankton viability, albeit slightly, when the whole sampling period is observed [linear regression, adjusted $R^{2}=0.15$, $F(1,28)=6.257, P=0.0185$, Fig. 5]. However, when the data are divided into seasons, this correlation is only significant during spring bloom [linear regression, $\left.R^{2}=0.55, F(1,6)=7.212, P=0.0363\right]$. POC:DOC ratio was not significantly related to viability or changes in DOC concentration. Neither suspended nor sinking POC, PON or Chl $a$ fractions were significantly related to viability.

There was no noticeable relationship between phytoplankton viability and the abundance of bacteria (total, HNA or LNA) during the total monitoring period. Occasionally, bacterial numbers increased during or immediately after a drop in viability, for example after spring and late summer blooms in 2015. In summer there was a significant inverse relationship between bacteria and viability (negative binomial GLM, generalized $R^{2}=0.53, P<0.001$ ).

Salinity varied mainly between 5 and 6 PSU. Two riverine inflow events dropped salinity below 4.5 PSU in surface water in January 2016 and during the spring bloom of 2016. The riverine inflows appeared to supply organic matter to the study site because there was a clear negative relationship between salinity and DOC [linear regression, adjusted $R^{2}=0.59, F(1$, 28) $=43.44, P<0.001$, Fig. 5]. DOC concentration was best explained by salinity and viability together [multiple linear regression, adjusted $R^{2}=0.64, F(2$, 27) $=26.54, P<0.001]$.

In 2015, when sampling included the $20 \mathrm{~m}$ depth, the whole measured water column appeared well mixed until the end of the spring bloom, as indicated by comparable bacterial abundances, DOC/N and $\mathrm{Chl}$ $a$ concentrations, and temperature differences between the surface and $20 \mathrm{~m}$. Toward the end of the summer these values started to diverge between 1 and $20 \mathrm{~m}$ and in fall the two depths were markedly different. At $20 \mathrm{~m}$ there was a positive relationship between salinity and all the measured nutrients indicating an inflow of nutrient-rich bottom water.

\section{Discussion}

Variation in phytoplankton viability

Phytoplankton community viability was always less than $100 \%$ (average of the whole sampling period: $62 \%$ ) meaning that at any given time a fraction of the community consists of dead cells. There was considerable variation in the community viability throughout the sampling period suggesting that the ecological consequences of phytoplankton cell death are not strictly limited to certain seasons or events, such as the demise of the spring bloom.

The viability of natural phytoplankton communities or individual phytoplankton groups in oceanic surface water can vary from almost $10 \%$ viable cells (AlonsoLaita \& Agustí, 2006) to near completely viable communities (Veldhuis et al., 2001; Agustí, 2004). Almost as large variability has been observed in freshwater systems (Agusti et al., 2006; Rychtecký et al., 2014; Kozik et al., 2019). Viability in our study varied between 18 and $97 \%$ and is therefore comparable to other studies. Viability of nano- and picophytoplankton was also studied on the open Baltic Proper by Vanharanta et al. (2020) who reported viabilities ranging between 60 and $90 \%$ with surface water mean of $85 \%$. We can therefore conclude that dying cells comprise an important proportion of the phytoplankton community in the Baltic Sea as in other systems.

There was a weak yet significant relationship between the total phytoplankton cell abundance and viability during the total sampling period, although within the individual seasons this relationship was observed only during winter and spring bloom. 
However, regression analyses within individual seasons were unreliable due to small number of observations, and therefore, we avoid drawing season specific conclusions. Out of a total of 38 viability measurements only 5 showed a viability less than $40 \%$ and these events of low viability invariably coincided with low phytoplankton abundance and low $\mathrm{Chl} a$ concentration. The lowest viabilities, therefore, occur when conditions were unfavorable overall for phytoplankton growth. High phytoplankton abundance was linked to high viability especially during 2015 spring bloom and during the peaks of the late summer blooms. During most other samplings there did not seem to be any relationship between phytoplankton viability and abundance. In cultures, phytoplankton viability is usually high during the growth phase and starts to drop at the stationary phase (Lee \& Rhee, 1997; Agustí \& Sánchez, 2002) but viability of a single phytoplankton group has also been shown to vary independent of the growth (Brussaard et al., 1997). This decoupling has also been observed in natural environments (Lasternas et al., 2010; Znachor et al., 2015). Surface water viability was the highest during the onset of 2015 spring bloom when $S$. marinoi dominated but about $15 \%$ of the cells were still membrane damaged. As conditions could be assumed optimal this fraction could be interpreted as the minimum amount of membrane damaged cells present in the $S$. marinoi community. High amount of membrane damaged cells in conditions which enable growth has also been demonstrated for another diatom Fragilaria crotonensis (Znachor et al., 2015). Species-specific differences in the proportion of membrane damaged cells during different growth phases might partially explain the lack of relationship between total community viability and environmental variables in this study; a dominating species might have their viability reduced by a specific limiting factor, e.g., nutrient concentration threshold, and therefore affect the viability of the whole community, whereas the viability of another species might be unaffected by the same factor in a similar growth phase.

Our results suggest viability to be high in communities with low diversity of the measured taxonomic groups. During the S. marinoi dominated 2015 spring bloom viability remained high $(>80 \%)$ throughout the bloom. On the contrary, during spring 2016 both viability and phytoplankton community composition were more variable than in 2015. During a period of
40 days a bloom consisting of approximately $50 \%$ of diatoms and $30 \%$ of dinoflagellates by biomass turned into a bloom consisting of approximately $25 \%$ of diatoms and $60 \%$ of dinoflagellates. This bloom had two Chl $a$ peaks and a transition period with lower phytoplankton abundance and a more mixed community (an important contribution from the group "other flagellates"). During this mixed 2016 bloom viability was much lower than during 2015 spring bloom, varying between 30 and $65 \%$. The rest of the dataset is less conclusive but on day 209 at the onset of the 2015 late summer bloom there was one more occasion when the phytoplankton community was dominated by only one group (dinoflagellates, mainly Heterocapsa triquetra) and the viability was high. Toward the next sampling on day 230 the phytoplankton biomass had almost doubled, the community became more mixed $(H=1.0)$, and viability dropped, although only from 87 to $81 \%$. The change in viability is nevertheless negative as opposed to the general trend of increased viability with higher phytoplankton abundance.

The connection between single group dominance and high viability can be seen on the three observations, when diversity was especially low (effectively a single species dominance) and viability was on the high end ( $>80 \%$ viable cells, Fig. 4 ). Two of these three observations were from the 2015 diatom dominated spring bloom and one from the dinoflagellate dominated day 209 of 2015 . Even though the viability varied from very high to very low values when diversity was high, and there was no direct correlation between the two variables, there were no cases where both viability and diversity would have been low. During early bloom high viability might be explained by the dominating population being actively proliferating. Another possible explanation for this is that single species blooms may escape the important mortality-inducing factors such as allelopathy (Vardi et al., 2002; Poulin et al., 2018). Increased production of allelopathic chemicals might be induced by the presence of competing species (Ikeda et al., 2016). Also, the polyunsaturated aldehydes released by diverse phytoplankton, especially diatoms (Wichard et al., 2005), have been shown, among other effects, to cause membrane permeability in other phytoplankton species (Casotti et al., 2005; Ribalet et al., 2007). Given the lack of other clear causes, allelopathy presents a potential explanation for low viability during many samplings when diversity was high. If 
this is the case the predicted increased competition between diatoms and dinoflagellates (Klais et al., 2011) might result in spring blooms with lower overall proportion of healthy phytoplankton cells.

Nutrient limitation can decrease the proportion of viable cells in phytoplankton cultures (Brussaard et al., 1997; Lee \& Rhee, 1997). Similarly natural phytoplankton viability has been linked with trophic regime, with higher values in eutrophic rather than in oligotrophic environments (Agusti et al., 2006; Alonso-Laita \& Agustí, 2006) and larger species especially can have low viability in oligotrophic environments (Alonso-Laita \& Agustí, 2006). Direct correlations between viability and nutrient concentrations have also been observed in oligotrophic environments (Lasternas et al., 2010). In our study, nutrient concentrations were found to have no direct correlation with viability. Depleted $\mathrm{NO}_{3}{ }^{-}$concentration and occasionally depleted $\mathrm{PO}_{4}{ }^{3-}$ concentration during the productive period suggest that the phytoplankton growth was mostly $\mathrm{N}$ limited, as is typical at the region (Tamminen \& Andersen, 2007), but periods of simultaneous $\mathrm{N}$ and $\mathrm{P}$ limitation might have occurred. Si concentration remained $>3.5 \mu \mathrm{mol} \mathrm{l}^{-1}$ even during periods of high diatom abundance suggesting that $\mathrm{Si}$ was never a limiting nutrient. Such independence between viability and apparent growthlimiting nutrients has also been shown in other environments for total phytoplankton community (Hayakawa et al., 2008; Alou-Font et al., 2016) or for individual species (Rychtecký et al., 2014; Kozik et al., 2019). The weak correlation between viability and nutrient concentrations on yearly scale can most likely be explained by seasonal changes in growth conditions; in winter nutrient concentrations are high but conditions are otherwise unfavorable for phytoplankton. The lack of a relationship during the productive season could perhaps be explained by effective nutrient turnover rates during the productive season at the study site. High bacterial abundance probably maintains high remineralization rate of riverine DOM (Asmala et al., 2013) producing enough fresh nutrients to support phytoplankton growth (Traving et al., 2017) while high phytoplankton biomass and turnover rates may nevertheless keep the nutrient concentrations (especially N) low through the productive season. Regardless, during summer when the nutrient concentrations were very low, viability was also lower than during any other season, which may indicate a very broad-scale relationship between nutrients and viability in this system.

Viral infection is an important cause for the presence of membrane compromised cells among different phytoplankton species (Brussaard et al., 2001; Laber et al., 2018). Virus-like particles are not in themselves a signal of active lytic infection on the phytoplankton, especially since they also include bacteriophages not capable of infecting phytoplankton. We found no correlation between VLP abundance and phytoplankton viability, and we did not find any increase in VLP in conjunction with the decline of any of the major blooms or during events of low viability, even though increase in VLP abundance has been linked to bloom termination in other systems (Bratbak et al., 1993; Hewson et al., 2001) and VLP abundance at the study site is high compared to many aquatic systems (Sekar \& Kandasamy, 2013). In the light of these results we cautiously propose that other mechanisms than viral lysis are more important drivers for variation in membrane-compromised phytoplankton cells in our study area. We must highlight, however, that using actual viral infection indicators might lead to different conclusions as VLP abundance is a very approximate estimation of virus activity.

Recent studies concerning cellular mechanisms of phytoplankton mortality suggest that viability of phytoplankton is determined by complex interaction of biotic and abiotic mechanisms (Bidle, 2015), with a significant contribution by inter- and intraspecific communication within the planktonic community. Our results can be interpreted according to this view; abiotic conditions alone cannot explain phytoplankton viability even though they set strict constraints on phytoplankton productivity and bloom formation. Instead viability seems to be high in those rare occasions, when the community is strongly dominated by single phytoplankton groups, or especially, single species and therefore interspecific harmful interactions can be assumed to be minimal.

Viability and organic matter cycling

Viability of the phytoplankton cells in the sediment trap was generally of the same magnitude as in the surface water, often even slightly higher. Viable diatoms accumulated in the sediment trap especially during the 2015 spring bloom and also during other seasons. Also motile phytoplankton, especially $H$. 
triquetra during the early fall bloom of 2015, contributed to the sinking viable cells. Generally, sinking of intact cells is associated with diatoms whereas dinoflagellates are assumed to lyse in the water column (Tamelander \& Heiskanen, 2004) unless there is an event of mass encystment (Heiskanen, 1993) but this time at least, a part of the healthy vegetative dinoflagellate cells was removed by sinking. Our results therefore suggest that in shallow estuaries sinking is an important loss process for most phytoplankton cells regardless of their viability, motility or tendency to lyse in the water column in other systems. The slightly higher viability in sediment traps compared to surface water suggests that some of the dying cells might lyse in the water column before sinking but this fraction was so small that it could not be related to the changes in surface water POC and DOC pools. It must be noted that our method did not capture the relationship between initiation of cell sinking and viability if loss of buoyancy regulation started before membrane disintegration in the cell death pathway. It is also possible that viable motile cells were brought temporarily into the sediment trap by mixing which may lead to overestimation of the viability of sinking phytoplankton. However, viability in surface water and sediment trap were similar even toward the end of the summer when the water column was more stratified, suggesting that mixing is not necessary for healthy cells to end up in the sediment trap.

Changes in viability did not result in detectable changes in the distribution of carbon into DOC or POC pools; we expected the DOC pool to have increased during periods when the abundance of membrane damaged cells was high (low viability). Even though in pooled analysis of all samplings surface water DOC concentration increased with decreasing viability, this connection was weak. On the seasonal scale this relationship was only detected during spring bloom. Altogether, seasonal variation in DOC and DON concentrations compared to POC and PON concentrations was minor. There was also no significant relationship between viability and POC. Together this results in surface water POC:DOC ratio being seemingly independent of viability. Viability also was never significantly related to sedimentation rates of POC, PON or Chl $a$ suggesting that cell death and lysis as a loss process is not critical for determining the fate of phytoplankton-derived carbon at the study site. Instead, high viability of phytoplankton in the sediment trap suggests that sinking is more important a loss process than lysis.

Detection of the release of fresh DOC from phytoplankton is complicated by the riverine input of organic matter. Salinity, which is a direct proxy for fresh water inflow, explains changes in DOC concentration much better than viability. However, the most optimal model for explaining DOC concentration includes both viability and salinity. This model explains up to $64 \%$ of the changes in DOC concentration (salinity alone: 59\%, viability alone: $15 \%$ ). Viability was not significantly related to salinity indicating that they produce independent impacts on DOC concentration. The salinity at $20 \mathrm{~m}$ was unaffected by the events of reduced salinity in the surface water, suggesting that the high-DOC riverine water mass did not mix thoroughly with bottom water at the sampling site. The negative relationship between DOC and salinity at $20 \mathrm{~m}$ is not as strong as in the surface, further suggesting that riverine fresh water inflow is indeed the main source of DOC.

Grazing by zooplankton was not measured in this study. Zooplankton grazing of phytoplankton at the study site has previously been shown to be weak in spring (Lignell et al., 1992). In summer grazing has been shown to be high (Uitto et al., 1997) although variable depending on the composition of the planktonic community (Uitto, 1996). We could therefore assume that our observations during spring accurately represent the relationship between phytoplankton viability and DOC release. In summer higher grazing pressure may instead direct more carbon toward the planktonic food web, and DOC release from sloppy feeding and excretion by zooplankton may overshadow the DOC release from dying phytoplankton cells.

It is assumed that the DOM leaking from dying cells is highly bioavailable and therefore rapidly consumed by pelagic heterotrophic bacteria, especially when bacterial biomass is high. During such times the assumed increased DOM leakage from membrane damaged cells could be assumed not to significantly influence the DOM pool, especially given the high background DOM concentrations of the sampling site. A significant negative relationship between viability and bacterial abundance could only be found in summer but there were instances through the sampling period when bacterial abundance was high and 
viability was low. These could be interpreted as fresh DOM being released from phytoplankton to bacteria. However, this interpretation must be taken cautiously since during the events of low viability also total phytoplankton abundance was mostly low. Therefore, the phytoplankton were not necessarily an important source of DOM for bacteria during those times. Instead, high bacterial abundance could be associated to earlier introduction of DOM into the system. During the spring bloom the higher contribution of HNA bacteria to the total bacterial community could be assumed to indicate bacterial utilization of phytoplankton-derived DOM as HNA cells have been attributed to copiotrophic bacteria capable of utilizing pulses of available organic carbon (Bouvier et al., 2007). Motile copiotrophic bacteria could be assumed to especially benefit from DOM release caused by increased lysis at the termination of the spring bloom (Smriga et al., 2016). Bacterial abundance was otherwise not significantly related to phytoplankton abundance. Especially the effect of nano- and microzooplankton grazing of bacteria, which was not quantified, could uncouple the accumulation of bacterial cells from bacterial production and adjacent DOM consumption. The main driver for bacterial abundance was likely temperature throughout the sampling period (data not shown).

\section{Conclusions}

Our results demonstrate that dead phytoplankton cells are a common component of the phytoplankton community in the Baltic Sea year around, at least in the coastal zone. Variation in phytoplankton viability could not clearly be explained by the environmental factors mainly thought to determine phytoplankton growth. High viability during periods of dominance by a single phytoplankton group suggests interspecific competition as one potential determinant of phytoplankton viability. Because there was no relationship between Chl $a$ and viability, we suggest caution when phytoplankton productivity is derived directly from Chl $a$ fluorescence by, e.g., remote sensing. Work to better describe the relationship between phytoplankton viability, primary production, and bacterial production would add sophistication to the important work of modeling the marine carbon cycle.
Acknowledgements Open access funding provided by University of Helsinki including Helsinki University Central Hospital. The research was funded by Walter and Andrée de Nottbeck foundation (SE, MD, TT) and the Swedish Cultural Foundation (TT). We thank the staff and interns of Tvärminne Zoological Station for support with sampling and analyses, and Charlotte Angove for proofreading. We kindly thank three anonymous reviewers for comments that helped improve the quality of the manuscript.

Author contributions All authors contributed to the study conception and design. Material preparation, data collection and analysis were performed by SE, MD and TT. The first draft of the manuscript was written by SE and all authors commented on previous versions of the manuscript. All authors read and approved the final manuscript.

\section{Compliance with ethical standards}

Conflict of interest None.

Open Access This article is licensed under a Creative Commons Attribution 4.0 International License, which permits use, sharing, adaptation, distribution and reproduction in any medium or format, as long as you give appropriate credit to the original author(s) and the source, provide a link to the Creative Commons licence, and indicate if changes were made. The images or other third party material in this article are included in the article's Creative Commons licence, unless indicated otherwise in a credit line to the material. If material is not included in the article's Creative Commons licence and your intended use is not permitted by statutory regulation or exceeds the permitted use, you will need to obtain permission directly from the copyright holder. To view a copy of this licence, visit http://creativecommons.org/licenses/by/4.0/.

\section{References}

Agustí, S., 2004. Viability and niche segregation of Prochlorococcus and Synechococcus cells across the Central Atlantic Ocean. Aquatic Microbial Ecology 36: 53-59.

Agustí, S. \& M. C. Sánchez, 2002. Cell viability in natural phytoplankton communities quantified by a membrane permeability probe. Limnology and Oceanography 47: $818-828$.

Agustí, S. \& C. M. Duarte, 2013. Phytoplankton lysis predicts dissolved organic carbon release in marine plankton communities. Biogeosciences 10: 1259-1264.

Agusti, S., E. V. A. Alou, M. V. Hoyer, T. K. Frazer \& D. E. Canfield, 2006. Cell death in lake phytoplankton communities. Freshwater Biology 51: 1496-1506.

Agusti, S., J. I. Gonzalez-Gordillo, D. Vaque, M. Estrada, M. I. Cerezo, G. Salazar, J. M. Gasol \& C. M. Duarte, 2015. Ubiquitous healthy diatoms in the deep sea confirm deep carbon injection by the biological pump. Nature Communications 6: 7608 . 
Alonso-Laita, P. \& S. Agustí, 2006. Contrasting patterns of phytoplankton viability in the subtropical NE Atlantic Ocean. Aquatic microbial ecology 43: 67-78.

Alou-Font, E., S. Roy, S. Agustí \& M. Gosselin, 2016. Cell viability, pigments and photosynthetic performance of Arctic phytoplankton in contrasting ice-covered and openwater conditions during the spring-summer transition. Marine Ecology Progress Series 543: 89-106.

Asmala, E., R. Autio, H. Kaartokallio, L. Pitkänen, C. Stedmon \& D. Thomas, 2013. Bioavailability of riverine dissolved organic matter in three Baltic Sea estuaries and the effect of catchment land use. Biogeosciences 10: 6969-6986.

Bar-Zeev, E., I. Avishay, K. D. Bidle \& I. Berman-Frank, 2013. Programmed cell death in the marine cyanobacterium Trichodesmium mediates carbon and nitrogen export. ISME Journal 7: 2340-2348.

Berges, J. A. \& P. G. Falkowski, 1998. Physiological stress and cell death in marine phytoplankton: induction of proteases in response to nitrogen or light limitation. Limnology and Oceanography 43: 129-135.

Berman-Frank, I., K. D. Bidle, L. Haramaty \& P. G. Falkowski, 2004. The demise of the marine cyanobacterium, Trichodesmium spp. via an autocatalyzed cell death pathway. Limnology and Oceanography 49: 997-1005.

Berman-Frank, I., G. Rosenberg, O. Levitan, L. Haramaty \& X. Mari, 2007. Coupling between autocatalytic cell death and transparent exopolymeric particle production in the marine cyanobacterium Trichodesmium. Environmental Microbiology 9: 1415-1422.

Bidle, K. D., 2015. The molecular ecophysiology of programmed cell death in marine phytoplankton. Annual Review of Marine Science 7: 341-375.

Bidle, K. D. \& P. G. Falkowski, 2004. Cell death in planktonic, photosynthetic microorganisms. Nature Reviews Microbiology 2: 643-655.

Bouvier, T., P. A. Del Giorgio \& J. M. Gasol, 2007. A comparative study of the cytometric characteristics of high and low nucleic-acid bacterioplankton cells from different aquatic ecosystems. Environmental Microbiology 9: 2050-2066.

Bratbak, G., J. K. Egge \& M. Heldal, 1993. Viral mortality of the marine alga Emiliania huxleyi (Haptophyceae) and termination of algal blooms. Marine Ecology Progress Series 93: $39-48$.

Brussaard, C. P. D., R. Riegman, A. A. M. Noordeloos, G. C. Cadée, H. Witte, A. J. Kop, G. Niuwland, F. C. van Dyul \& R. P. M. Bak, 1995. Effects of grazing, sedimentation and phytoplankton cell lysis on the structure of a coastal pelagic food web. Marine Ecology Progress Series 123: 259-271.

Brussaard, C. P. D., A. A. M. Noordeloos \& R. Riegman, 1997. Autolysis kinetics of the marine diatom Ditylum brightwellii (Bacillariophyceae) under nitrogen and phosphorus limitation and starvation. Journal of Phycology 33: 980-987.

Brussaard, C. P. D., D. Marie, R. Thyrhaug \& G. Bratbak, 2001. Flow cytometric analysis of phytoplankton viability following viral infection. Aquatic Microbial Ecology 26: 157-166.

Carrias, J.-F., J.-P. Serre, T. Sime-Ngando \& C. Amblard, 2002. Distribution, size, and bacterial colonization of pico- and nano-detrital organic particles (DOP) in two lakes of different trophic status. Limnology and Oceanography 47: 1202-1209.

Casotti, R., S. Mazza, C. Brunet, V. Vantrepotte, A. Ianora \& A. Miralto, 2005. Growth inhibition and toxicity of the diatom aldehyde 2-trans, 4-trans-decadienal on Thalassiosira weissflogii (Bacillariophyceae). Journal of Phycology 41: 7-20.

Davey, H. M., 2011. Life, death, and in-between: meanings and methods in microbiology. Applied and Environmental Microbiology 77: 5571-5576.

Dunne, J. P., J. L. Sarmiento \& A. Gnanadesikan, 2007. A synthesis of global particle export from the surface ocean and cycling through the ocean interior and on the seafloor. Global Biogeochemical Cycles. https://doi.org/10.1029/ 2006 GB002907.

Durand, P. M., S. Sym \& R. E. Michod, 2016. Programmed cell death and complexity in microbial systems. Current Biology 26: R587-R593.

Edwards, B. R., K. D. Bidle \& B. A. Van Mooy, 2015. Dosedependent regulation of microbial activity on sinking particles by polyunsaturated aldehydes: implications for the carbon cycle. Proceedings of the National Academy of Sciences of the United States of America 112: 5909-5914.

Eppley, R. W., R. W. Holmes \& J. D. H. Strickland, 1967. Sinking rates of marine phytoplankton measured with a fluorometer. Journal of Experimental Marine Biology and Ecology 1: 191-208.

Fleming-Lehtinen, V., M. Laamanen, H. Kuosa, H. Haahti \& R. Olsonen, 2008. Long-term development of inorganic nutrients and chlorophyll $\alpha$ in the open northern Baltic Sea. AMBIO: A Journal of the Human Environment 37: 86-92.

Franklin, D. J., C. P. D. Brussaard \& J. A. Berges, 2006. What is the role and nature of programmed cell death in phytoplankton ecology? European Journal of Phycology 41: $1-14$.

Gasol, J. M., U. L. Zweifel, F. Peters, J. A. Fuhrman \& A. Hagstrom, 1999. Significance of size and nucleic acid content heterogeneity as measured by flow cytometry in natural planktonic bacteria. Applied and Environmental Microbiology 65: 4475-4483.

Gemmell, B. J., G. Oh, E. J. Buskey \& T. A. Villareal, 2016. Dynamic sinking behaviour in marine phytoplankton: rapid changes in buoyancy may aid in nutrient uptake. Proceedings of the Royal Society B: Biological Sciences. https://doi.org/10.1098/rspb.2016.1126.

Grasshoff, K., M. Ehrhardt \& K. Kremling, 1983. Methods of Seawater Analysis. Verlag Chemie, Weinheim.

Gregg, M. D. \& G. M. Hallegraeff, 2007. Efficacy of three commercially available ballast water biocides against vegetative microalgae, dinoflagellate cysts and bacteria. Harmful Algae 6: 567-584.

Hayakawa, M., K. Suzuki, H. Saito, K. Takahashi \& S.-I. Ito, 2008. Differences in cell viabilities of phytoplankton between spring and late summer in the northwest Pacific Ocean. Journal of Experimental Marine Biology and Ecology 360: 63-70.

Heiskanen, A. S., 1993. Mass encystment and sinking of dinoflagellates during a spring bloom. Marine Biology 116: 161-167. 
HELCOM, 2015. Manual for Marine Monitoring in the COMBINE Programme of HELCOM [available on internet at http://www.helcom.fi/action-areas/monitoring-andassessment/manuals-and-guidelines/combine-manual]. Updated February 2015.

Hewson, I., J. M. O’Neil \& W. C. Dennison, 2001. Virus-like particles associated with Lyngbya majuscula (Cyanophyta; Oscillatoriacea) bloom decline in Moreton Bay, Australia. Aquatic Microbial Ecology 25: 207-213.

Hoikkala, L., P. Kortelainen, H. Soinne \& H. Kuosa, 2015. Dissolved organic matter in the Baltic Sea. Journal of Marine Systems 142: 47-61.

Ikeda, C. E., W. P. Cochlan, C. M. Bronicheski, V. L. Trainer \& C. G. Trick, 2016. The effects of salinity on the cellular permeability and cytotoxicity of Heterosigma akashiwo. Journal of Phycology 52: 745-760.

Jiao, N., G. J. Herndl, D. A. Hansell, R. Benner, G. Kattner, S. W. Wilhelm, D. L. Kirchman, M. G. Weinbauer, T. Luo, F. Chen \& F. Azam, 2010. Microbial production of recalcitrant dissolved organic matter: long-term carbon storage in the global ocean. Nature Reviews Microbiology 8: 593-599.

Kahl, L. A., A. Vardi \& O. Schofield, 2008. Effects of phytoplankton physiology on export flux. Marine Ecology Progress Series 354: 3-19.

Klais, R., T. Tamminen, A. Kremp, K. Spilling \& K. Olli, 2011. Decadal-scale changes of dinoflagellates and diatoms in the anomalous Baltic Sea spring bloom. PLoS ONE 6: e21567.

Kozik, C., E. B. Young, C. D. Sandgren \& J. A. Berges, 2019. Cell death in individual freshwater phytoplankton species: relationships with population dynamics and environmental factors. European Journal of Phycology 54: 369-379.

Kroemer, G., L. Galluzzi, P. Vandenabeele, J. Abrams, E. S. Alnemri, E. H. Baehrecke, M. V. Blagosklonny, W. S. El-Deiry, P. Golstein, D. R. Green, M. Hengartner, R. A. Knight, S. Kumar, S. A. Lipton, W. Malorni, G. Nuñez, M. E. Peter, J. Tschopp, J. Yuan, M. Piacentini, B. Zhivotovsky \& G. Melino, 2009. Classification of cell death: recommendations of the Nomenclature Committee on Cell Death 2009. Cell Death and Differentiation 16: 3-11.

Kwon, E. Y., F. Primeau \& J. L. Sarmiento, 2009. The impact of remineralization depth on the air-sea carbon balance. Nature Geoscience 2: 630-635.

Laber, C. P., J. E. Hunter, F. Carvalho, J. R. Collins, E. J. Hunter, B. M. Schieler, E. Boss, K. More, M. Frada, K. Thamatrakoln, C. M. Brown, L. Haramaty, J. Ossolinski, H. Fredericks, J. I. Nissimov, R. Vandzura, U. Sheyn, Y. Lehahn, R. J. Chant, A. M. Martins, M. J. L. Coolen, A. Vardi, G. R. DiTullio, B. A. S. Van Mooy \& K. D. Bidle, 2018. Coccolithovirus facilitation of carbon export in the North Atlantic. Nature Microbiology 3: 537-547.

Lasternas, S., S. Agustí \& C. M. Duarte, 2010. Phyto- and bacterioplankton abundance and viability and their relationship with phosphorus across the Mediterranean Sea. Aquatic Microbial Ecology 60: 175-191.

Lasternas, S., M. Piedeleu, P. Sangrà, C. M. Duarte \& S. Agustí, 2013. Forcing of dissolved organic carbon release by phytoplankton by anticyclonic mesoscale eddies in the subtropical NE Atlantic Ocean. Biogeosciences 10: 2129-2143.
Lee, D.-Y. \& G. Y. Rhee, 1997. Kinetics of cell death in the cyanobacterium Anabaena flos-aquae and the production of dissolved organic carbon. Journal of Phycology 33: 991-998.

Lignell, R., S. Kaitala \& H. Kuosa, 1992. Factors controlling phyto- and bacterioplankton in late spring on a salinity gradient in the northern Baltic. Marine Ecology Progress Series 84: 121-131.

Luhtanen, A. M., E. Eronen-Rasimus, H. Kaartokallio, J. M. Rintala, R. Autio \& E. Roine, 2014. Isolation and characterization of phage-host systems from the Baltic Sea ice. Extremophiles 18: 121-130.

Menden-Deuer, S. \& E. J. Lessard, 2000. Carbon to volume relationships for dinoflagellates, diatoms and other protist plankton. Limnology and Oceanography 45: 569-579.

Orellana, M. V., W. L. Pang, P. M. Durand, K. Whitehead \& N. S. Baliga, 2013. A role for programmed cell death in the microbial loop. PLoS ONE 8: e62595.

Padisák, J., É. Soróczki-Pintér \& Z. Rezner, 2003. Hydrobiologia 501: 219-219.

Pedler, B. E., L. I. Aluwihare \& F. Azam, 2014. Single bacterial strain capable of significant contribution to carbon cycling in the surface ocean. Proceedings of the National Academy of Sciences of the United States of America 111: 7202-7207.

Peperzak, L. \& C. P. Brussaard, 2011. Flow cytometric applicability of fluorescent vitality probes on phytoplankton. Journal of Phycology 47: 692-702.

Poulin, R. X., S. Hogan, K. L. Poulson-Ellestad, E. Brown, F. M. Fernandez \& J. Kubanek, 2018. Karenia brevis allelopathy compromises the lipidome, membrane integrity, and photosynthesis of competitors. Scientific Reports 8: 9572.

Ribalet, F., J. A. Berges, A. Ianora \& R. Casotti, 2007. Growth inhibition of cultured marine phytoplankton by toxic algalderived polyunsaturated aldehydes. Aquatic Toxicology 85: 219-227.

Ross, C., B. C. Warhurst, A. Brown, C. Huff \& J. D. Ochrietor, 2019. Mesohaline conditions represent the threshold for oxidative stress, cell death and toxin release in the cyanobacterium Microcystis aeruginosa. Aquatic Toxicology 206: 203-211.

Rychtecký, P., P. Znachor \& J. Nedoma, 2014. Spatio-temporal study of phytoplankton cell viability in a eutrophic reservoir using SYTOX Green nucleic acid stain. Hydrobiologia 740: 177-189.

Sarmento, H. \& J. M. Gasol, 2012. Use of phytoplanktonderived dissolved organic carbon by different types of bacterioplankton. Environmental Microbiology 14: 2348-2360.

Sekar, A. \& K. Kandasamy, 2013. Bacterial viruses in marine environment and their ecological role and bioprospecting potential: a review. International Journal of Current Microbiology and Applied Sciences 2: 151-163.

Smayda, T. J. \& B. J. Boleyn, 1965. Experimental observations on the flotation of marine diatoms. I. Thalassiosira $\mathrm{Cf}$. Nana, Thalassiosira rotula and Nitzschia seriata. Limnology and Oceanography 10: 499-509.

Smriga, S., V. I. Fernandez, J. G. Mitchell \& R. Stocker, 2016. Chemotaxis toward phytoplankton drives organic matter partitioning among marine bacteria. Proceedings of the 
National Academy of Sciences of the United States of America 113: 1576-1581.

Spilling, K., K. Olli, J. Lehtoranta, A. Kremp, L. Tedesco, T. Tamelander, R. Klais, H. Peltonen \& T. Tamminen, 2018. Shifting diatom-dinoflagellate dominance during spring bloom in the Baltic Sea and its potential effects on biogeochemical cycling. Frontiers in Marine Science. https:// doi.org/10.3389/fmars.2018.00327.

Tamelander, T. \& A.-S. Heiskanen, 2004. Effects of spring bloom phytoplankton dynamics and hydrography on the composition of settling material in the coastal northern Baltic Sea. Journal of Marine Systems 52: 217-234.

Tamminen, T. \& T. Andersen, 2007. Seasonal phytoplankton nutrient limitation patterns as revealed by bioassays over Baltic Sea gradients of salinity and eutrophication. Marine Ecology Progress Series 340: 121-138.

Thornton, D. C. O., 2014. Dissolved organic matter (DOM) release by phytoplankton in the contemporary and future ocean. European Journal of Phycology 49: 20-46.

Thornton, D. C. O. \& J. Chen, 2017. Exopolymer production as a function of cell permeability and death in a diatom (Thalassiosira weissflogii) and a cyanobacterium (Synechococcus elongatus). Journal of Phycology 53: 245-260.

Titman, D. \& P. Kilham, 1976. Sinking in freshwater phytoplankton: some ecological implications of cell nutrient status and physical mixing processes. Limnology and Oceanography 21: 409-417.

Traving, S. J., O. Rowe, N. M. Jakobsen, H. Sorensen, J. Dinasquet, C. A. Stedmon, A. Andersson \& L. Riemann, 2017. The effect of increased loads of dissolved organic matter on estuarine microbial community composition and function. Frontiers in Microbiology 8: 351.

Turner, J. T., 2015. Zooplankton fecal pellets, marine snow, phytodetritus and the ocean's biological pump. Progress in Oceanography 130: 205-248.

Uitto, A., 1996. Summer time herbivory of coastal mesozooplankton and metazoan microplankton in the northern Baltic. Marine Ecology Progress Series 132: 47-56.
Uitto, A., A.-S. Heiskanen, R. Lignell, R. Autio \& R. Pajuniemi, 1997. Summer dynamics of the coastal planktonic food web in the northern Baltic Sea. Marine Ecology Progress Series 151: 27-41.

Vanharanta, M., S. Elovaara, D. Franklin, K. Spilling \& T. Tamelander, 2020. Viability of pico- and nanophytoplankton in the Baltic Sea during spring. Aquatic Ecology 54: 119-135.

Vardi, A., D. Schatz, K. Beeri, U. Motro, A. Sukenik, A. Levine \& A. Kaplan, 2002. Dinoflagellate-cyanobacterium communication may determine the composition of phytoplankton assemblage in a mesotrophic lake. Current Biology 12: 1767-1772.

Vardi, A., F. Formiggini, R. Casotti, A. De Martino, F. Ribalet, A. Miralto \& C. Bowler, 2006. A stress surveillance system based on calcium and nitric oxide in marine diatoms. PLoS Biology 4: e60.

Veldhuis, M., G. Kraay \& K. Timmermans, 2001. Cell death in phytoplankton: correlation between changes in membrane permeability, photosynthetic activity, pigmentation and growth. European Journal of Phycology 36: 167-177.

Wichard, T., S. A. Poulet, C. Halsband-Lenk, A. Albaina, R. Harris, D. Liu \& G. Pohnert, 2005. Survey of the chemical defence potential of diatoms: screening of fifty species for $\alpha, \beta, \gamma, \delta$-unsaturated aldehydes. Journal of Chemical Ecology 31: 949-958.

Znachor, P., P. Rychtecký, J. Nedoma \& V. Visocká, 2015. Factors affecting growth and viability of natural diatom populations in the meso-eutrophic Římov Reservoir (Czech Republic). Hydrobiologia 762: 253-265.

Zuur, A. F., E. N. Ieno \& C. S. Elphick, 2010. A protocol for data exploration to avoid common statistical problems. Methods in Ecology and Evolution 1: 3-14.

Publisher's Note Springer Nature remains neutral with regard to jurisdictional claims in published maps and institutional affiliations. 